\title{
TECHNOLOGY EDUCATION AND RESEARCH IN AUSTRALIA: A COMING OF AGE IN THE $21^{\text {ST }}$ CENTURY
}

\section{INTRODUCTION}

This chapter provides an analysis of the development of the field of technology education in Australia over the last decade. Three lines of argument are advanced. Firstly,, while there have been significant advances since the introduction of the Technology Key Learning Area (KLA), there are important challenges to its further development. Secondly, there is a greater level of cooperation between technology education researchers, administrators, schools and teachers, than previously, aimed at improving the quality of technology education in schools. Finally, technology education researchers are discovering, through necessity, new ways of researching teaching and learning in technology education, which are contributing to educational research methods generally. However, there remain within this picture tensions and contradictions that need to be resolved.

A little over ten years ago I presented an analysis of technology education in Australia (Middleton, 1997). At that stage the eight key learning areas were still relatively new, with the National curriculum documents having been produced three years before (Curriculum Corporation, 1994a; 1994b). Agreement existed across the states and territories that the Technology KLA would become the basis for individual states' curriculum and syllabus documents, at least up to the end of junior high school (Year 10, or approximately 16 years of age). The picture in terms of research at that time was less encouraging, with few research projects and fewer technology education academics possessing doctoral degrees or the research experience necessary to be successful with research grant applications.

The new Technology KLA was defined as including industrial technology, information and communications technology, home economics, business, agriculture, and media. A professional association, the Technology Education Federation of Australia (TEFA), was established with a board made up of representatives from existing subject associations and a number of cross-curricular associations such as the Design in Education Council of Australia (DECA). TEFA was established to provide support for the new curriculum directions, and was a response to the then-federal government desire to channel funding for such activities as professional development through professional associations rather than state departments of education. As a single national body, TEFA acted as the 
broker between the federal government and the various professional associations, which, being largely state-based, consisted of over thirty groups.

Progress in implementing the Technology KLA has been relatively slow for a variety of reasons. In primary schooling, the introduction of the eight KLA's determined that change would be required in all areas, not just in technology. States adopted a staged approach, which determined that the introduction of technology was governed by its place in the schedule for implementation within each state. Other issues such as a lack of sufficient professional development for teachers who had not previously taught technology education, and who were not trained to do so, also tended to act as a brake on progress. Despite this, there has been a lot of enthusiasm from primary teachers (Williams, 2001; 2006), who see the value of technological activities in the learning experiences of primary-aged students and the potential of the Technology KLA as an integrator with other areas.

At the secondary level the picture has been mixed, with schools responding in various ways. Some regarded the Technology KLA, with its emphasis on a design process, as a natural extension and endorsement of the existing approach already adopted. Others saw the KLA as a threat to what they regarded as a quasivocational area of the curriculum and a new direction they were ill-equipped to address. Added to this was the issue in some schools of working out how to create a single Technology KLA in a situation where a school might have five existing subject areas that could make a claim to the title.

\section{TECHNOLOGY EDUCATION IN THE $21^{\text {ST }}$ CENTURY}

Moving forward to 2008, the picture has predictably changed again in all states. The most positive development over the last decade has been the more general introduction of technology education into primary schooling and primary teacher education programmes. However, the most pervasive current issue is the vocational education and training (VET) agenda, introduced by the previous conservative government and re-emphasised by the current labour government. Added to this is the critical shortage of technology teachers and the difficulty of attracting students into teacher education programmes. This shortage is matched by a shortage of technology education academics.

Australia has a governance and education system/s similar to the USA in that the federal government provides some of the funding for education but the organisation and delivery of education is undertaken by state governments. Given this, it would be impractical to deal with the minutia of differences in policy and practice across the states. I have taken the approach of outlining changes that are occurring across all states. Although there may be variation in how they are occurring, they are still there. For example, there is a strong VET agenda in all states, however, there is some variation across states in the details of how it is being implemented. The balance of this paper will draw examples from Queensland to support or illustrate my arguments, 


\section{Primary Technology Education}

One of the most exciting developments over the last decade has been the implementation of technology education in primary schooling. The introduction has not been widespread and some of the practices may be questionable, such as instances where technology education is equated with the more narrowly defined information and communication technology (ICT). However, where it has been introduced in the spirit and intent of the Technology KLA, the results in terms of student learning have been impressive. For example, interviews with the principal and some of the teachers at a particular primary school, and observations of a year 4/5 composite class presenting their technology projects (Williams, 2001), suggested that students had a sophisticated understanding of the nature of technology and of how they might use that knowledge in living their lives and making decisions. The projects being undertaken in the school were such that they integrated other areas of the curriculum so there appeared to be no sense in which teachers thought that technology education was something extra to fit into their teaching programmes. It needs to be said, however, that the school in question had sought and received significant professional development support.

\section{Primary Teacher Education}

A related development over the last ten years has been the introduction of technology education into primary teacher education programmes (Chester, 2002). This has been significant, given that Watts (1997) found that many primary teachers felt they were not sufficiently qualified to teach either science or technology and as a consequence tended to avoid or minimise these areas of the curriculum. Watts (ibid) further noted that the background of many primary teachers contributed to this feeling of a lack of capacity, given that many come to teaching with a social science/humanities background and inclination.

Chester reported in 2002 that of the 33 out of 39 universities in Australia offering primary teacher education programmes, most included a technology education component and about a third stipulated technology education as a compulsory course. Taking the Bachelor of Education (Primary) at Griffith University as an example, the response to these courses appears to have been positive, despite the course being only 10 credit points over one semester. Specifically, students in the BEd(Primary) have requested further courses, and a number take courses in the secondary Bachelor of Technology Education programmeme (BTechEd) as electives.

\section{The Vocational Education and Training (VET) Agenda}

Over the last decade, an increasing shortage of skilled workers has occurred in Australia in a range of industries, including building and construction, mining, and trade areas generally. The main reason for this is a strengthening economy flowing from increasing raw materials exports, principally to China and India. This has led 
to strong demand for skilled labour in all areas of the minerals, energy, and other raw materials and associated industries. The strong demand has led to attractive salaries for work in these areas. However, many of these jobs are in regional and remote areas of Australia and have attracted skilled workers from major population centres. This has led to calls for increased temporary migration visas, an increase in vocational education and training (VET) provision, and initiatives to make VET qualifications more attractive (Smith, 2004; Curriculum Corporation, 2005). This has been achieved by a combination of strong marketing and mechanisms such as the establishment of pathways between VET qualifications and university programmes (Pavlova, in press). For example, the previous conservative government responded to the shortage by introducing a number of initiatives designed to introduce VET courses into the upper years of schooling to encourage more students to enter trades.

With the election of the labour government in November 2007, the VET in schools initiative gained greater impetus, with the government committed to having a new VET centre in all high schools. Communications with the new Minister for Education (Williams, P.J., personal communication, 2008) suggest that there is little understanding of the concept of technology education as a component of general education. In the response to a letter to the Minister seeking clarification of the role the new government sees for technology education, the Minister appeared to see technology education as either computer education or VET. Whilst it is still early days for the government, this view represents a serious threat to the work of establishing technology education as a key learning area.

\section{Teacher Education Programmes}

An issue that has emerged over the last three years, related to the skills shortage noted above, is the difficulty of attracting sufficient numbers of suitably qualified students into technology education programmes. Most technology teacher education programmes have intakes that consist of varying proportions of school leavers and mature entry students (Chester, 2002). Many of this latter group have a trade or industry background, and this usually gains them credit and reduces the length of the programme for them. However, with the increasing skill shortages and increasing wages on offer to tradespeople, the mature entry cohort has virtually disappeared in many universities. In addition, the possibility of obtaining generous wages for even semi-skilled or unskilled occupations has had the effect of reducing interest in university study overall, including technology education programmes, by qualified school leavers.

Governments and universities have responded to the shortage of technology teachers in three principal ways. Firstly, they are retraining teachers from areas of the curriculum not in such high demand, such as the social sciences or business, to enable them to teach in areas of high demand. Currently, these include mathematics, science, and technology education. Starting in 2008, Education Queensland has also provided 200 scholarships for teacher retraining, with 30 allocated specifically to retraining teachers to become technology teachers. 
Secondly, universities are developing one year, graduate diploma courses to attract graduates from areas, such as engineering, architecture, industrial design, and drafting, into technology teaching. Graduate diplomas in other areas have proven to be popular with students. Thirdly, existing programmes are being reviewed and revised with the major purpose of shortening them or making parts available by external mode to reduce the cost to students and to produce graduates in a reduced time frame.

\section{Technology Education Academics}

A looming issue in Australia that appears to be mirrored in most western countries is the growing shortage of technology education academics (Williams, 2002). The shortage is occurring in teacher education generally and appears to be related to salaries and career advancement. For example, the salary of a teacher with a basic bachelor's degree can quickly rise to a level that is higher than a mid-range academic, who will need to have three degrees to progress to a level where their salary is equal to a high school head of department or higher. Further, the requirement of doctoral qualifications precludes the previous practice of recruiting experienced and innovative teachers as lecturers. As a consequence, it is often the case that when lecturing positions are advertised, there are no suitable applicants and the positions go unfilled. Although some technology education teachers are currently undertaking doctoral studies, these are almost always part-time so there is a long lead time between commencement of studies and completion, typically around seven years.

\section{NEW LEVEL OF COOPERATION BETWEEN RESEARCHERS, SCHOOLS, AND EDUCATION AUTHORITIES}

One factor that has contributed to an increase in technology education research is the connections being developed between researchers, schools, teachers, teacher professional organisations, and education departments. One example to illustrate this is the Working Together to Improve Practice project (Middleton \& Gooch, 2002). This was an action research project to examine the introduction of new teaching initiatives in six selected schools throughout Queensland. The project was funded by the Industrial Technology and Design Association of Queensland (INTAD). INTAD organised the call for expressions of interest to participate in the project and funded the six school-based projects as well as the parallel action research. The collaboration was important in providing some interesting and unexpected findings. For example, because the project involved schools in both metropolitan and rural locations, a monthly teleconference was built into the project. This was seen initially as a convenient way for teachers to provide feedback and was conceptualised as a form of focus group. However, an interesting phenomenon occurred over the course of the project: Although teachers were initially reluctant to share anything but good news about the project, by about the third teleconference this changed and teachers were engaging with each other, 
seeking help and ideas, and providing feedback to the research team. The teleconferences thus developed a life of their own that was nevertheless consistent with an action research methodology.

The national research project chaired by Williams (2001) is another example of collaboration where researchers had high levels of cooperation from schools in conducting a national study of the status of technology education in primary and secondary schools across Australia. Although such access may not seem unusual to researchers outside Australia, state governments within Australia have generally been reluctant to become involved in comparative studies that may show one state in an unfavourable light with respect to another.

Evidence of collaboration has extended more recently to state departments of education, with technology education researchers invited and funded to undertake research by these departments. A recent example is the Researching School Change in Technology Education project (Middleton, Chester, Finger, JamiesonProctor, \& Pavlova, 2004). This research project examined teacher change and adjustment of practice in response to the new Technology syllabus. The project brief was developed collaboratively by Griffith academic staff and technology education consultants from Education Queensland (EQ), and EQ officers facilitated access to schools for data collection. This was crucial in terms of rural schools where no established relationship existed or would have been impractical without EQ assistance.

Another example can be found in the decision by Education Queensland to provide full funding for 20 exemplary technology teachers (a mix of primary and secondary teachers) to attend the International Technology Education Research Conference (TERC08) hosted by Griffith University and held every two years on the Gold Coast. This is a considerable commitment to ensuring that the connection between technology education researchers and technology teachers is established and maintained.

A final example to illustrate the levels of cooperation is the access to schools being provided to university students, including honours, masters and doctoral research students. This is particularly encouraging given that it is occurring at a time of increasing constraints in terms of issues such as ethics requirements, where schools might well have responded that it was too difficult to have researchers working with teachers, and particularly students. If anything, the opposite is happening, with some schools initiating contact with researchers. A recent project by Walmsley (2008) in schools that was reasonably invasive involved a complex data collection system including simultaneous videorecording of student classroom activity with one camera and teacher activity with another, with a system for recording both activities as parallel data streams. This was followed by stimulated recall sessions with the teachers. Walmsley was able to achieve high levels of cooperation from teachers and school administrators, who were prepared to go to some lengths to accommodate his research and were interested in exploring the implications of his findings for classroom practice. 


\section{NEW WAYS OF RESEARCHING TECHNOLOGY EDUCATION}

Research in technology education in Australia is a relatively recent phenomena related to changes in the higher education sector. Prior to the early 1990s, higher education in Australia was comprised of universities and colleges of advanced education (CAE). Most research was conducted in universities and bodies like the Australian Research Council did not provide research funding for the CAE sector. In addition, CAEs were restricted to providing undergraduate and masters level programmes, so the kinds of research associated with a doctoral programme and the academic staff associated with it did not generally occur within CAEs.

The significance of this for education generally, and technology education specifically, was that most education faculties and all technology education programmes were within the Colleges of Advanced Education (CAE) sector. This changed as a result of the recommendations contained in the Dawkins (1987) paper. Dawkins was the federal Minister for Education and the paper recommended that there be one higher education sector consisting of universities; CAEs were to either amalgamate with existing universities (as happened with the Hunter Institute for Higher Education and Newcastle University) or become universities themselves (as happened with the Canberra CAE, now the University of Canberra). This change determined that research funding and the imperative to undertake research became part of the role for technology education academic staff.

As a result of the change, technology education academic staff began to engage in research, initially to gain doctoral qualifications. However, given the limited number of PhD-qualified academic staff in technology education, and thus few doctoral supervisors within technology education, the research undertaken in these early days was rooted in the traditions and methods of the humanities and social sciences and paid little heed to the particular features of learning and teaching in technology. As an example, much of the early research made the assumption, common in social science research, that human thinking is represented via speech or verbal renditions of thought. This assumption was made despite the fact that much thinking in technology education is multi-modal. That is, thinking is represented by both abstract codes, analogous to text, and by visual mental imagery.

By 2008 this has changed. For example, in a book on research methods and techniques (Middleton, 2008a) six Australian authors (as well as authors from a number of other countries) present chapters on research projects. However, the focus of the book was not on research per se, but on new research methods or techniques (Middleton, 2008b), with 'new' being defined as new to technology education research, or new in the sense that the way the method was being used was new. The chapters included descriptions and analyses of methods including: knowledge elicitation techniques for exploring expertise in Computer Aided Design (CAD) usage (Chester, 2008); cultural-historical approaches to understanding primary students' concept formation in technology education (Fleer, 2008); a new approach to comparative research methods (Pavlova, 2008); a case 
study approach to uncovering contextualised knowledge (Stevenson, 2008); an information technology enhanced stimulated recall technique for understanding what 'presses' technology education students into engaging in higher-order thinking (Walmsley, 2008); and a method for capturing and analysing concurrent verbal and visual data or technological problem-solving activity (Middleton, 2008c).

\section{TENSIONS AND CONTRADICTIONS}

Despite significant developments in technology education over the last decade, a number of tensions and contradictions exist in the current state of technology education in Australia, including:

- Whilst stronger, more coherent bachelor degrees of sufficient length to provide an appropriate balance of breadth and depth of technological knowledge for students have been developed over the last ten to fifteen years, these are being threatened by the strong demand for shorter programmes, such as graduate diplomas, which have difficulty in covering the breadth of content required by a technology education teacher;

- Whilst the introduction of Technology education into primary teacher education programmes has been a recent success, the reduction in four-year primary teacher education courses and the introduction of one-year graduate diplomas reduces the exposure to technology education by students to a portion of one integrated course;

- As a result of research (Pavlova, 2003) and practice (Martin \& Middleton, 2003) over the last decade, technology education academics have a clearer concept of what a good technology education programme contains, but against this is the strong vocational direction of both state and federal governments;

- Improved research connections with schools have the potential to be threatened or seen as irrelevant by the more instrumental approach embodied in the competency-based approach to vocational education; and

- Whilst there are now demonstrably better and more research being undertaken into technology education, the current government's emphasis on vocational education means that the possibility of changed priorities for research funding cannot be ruled out.

\section{CONCLUSIONS}

This chapter explores the issues and developments in technology education research and practice in Australia in the ten years to 2008. The argument is advanced that important developments in terms of curricula, research, and collaboration between technology education researchers have occurred. However, the chapter also argues that significant challenges exist in terms of shortages of technology teachers and teacher educators, but that important work has been and is being undertaken in terms of research and dissemination of that research within 


\section{COMING OF AGE IN THE $21^{\text {ST }}$ CENTURY}

schools. Finally, the chapter identifies a number of tensions and contradictions that confront technology educators as we move forward.

\section{REFERENCES}

Chester, I. (2008). Researching expertise development in complex computer applications. In H.E. Middleton (Ed.). Researching technology education: Methods and techniques (pp. 70-88). In International Technology Education Series. Rotterdam/Taipei: Sense.

Curriculum Corporation. (1994a). Technology statement. Melbourne: Curriculum Corporation.

Curriculum Corporation. (1994b). Technology statement and profiles. Melbourne: Curriculum Corporation.

Curriculum Corporation. (2005). New framework for vocational education in schools: A comprehensive guide about pathways for young Australians in transition. In Policy Directions. Melbourne: Curriculum Corporation \& Ministerial Council on Employment, Education and Youth Affairs.

Dawkins, J. (1987). Higher education: A policy discussion paper. Canberra: Australian Government.

Fleer, M. (2008). A cultural-historical perspective on research in design and technology education. In H.E. Middleton (Ed.), Researching technology education: Methods and techniques (pp. 89-98). In International Technology Education Series. Rotterdam/Taipei: Sense.

Martin, E., \& Middleton, H. E. (Eds.) (2003) Initiatives in technology education: Comparative perspectives, Proceedings of the American-Australian Technology Education Forum, Technical Foundation of America \& Centre for Technology Education Research, Griffith University.

Middleton, H.E. (1997). Technology education in Australia: Moving towards a new basic. Keynote address at the International Conference on Technology Education in the Asia/Pacific Region (ICTE 97). National Taiwan Normal University, Taipei, Taiwan.

Middleton, H.E. (Ed.) (2008a). Researching technology education: Methods and techniques. In International Technology Education Series. Rotterdam/Taipei: Sense.

Middleton, H.E. (2008b). Researching technology education: New ways of understanding teaching, learning, and knowledge. In H.E. Middleton (Ed.), Researching technology education: Methods and techniques (pp. 1-5). In International Technology Education Series. Rotterdam/Taipei: Sense.

Middleton, H.E. (2008c). Examining design thinking: Visual and verbal protocol analysis. In H.E. Middleton (Ed.), Researching technology education: Methods and techniques (pp. 193-212). In International Technology Education Series. Rotterdam/Taipei: Sense.

Middleton, H.E., Chester, I., Finger, G., Jamieson-Proctor, R., \& Pavlova, M. (2004). Researching school change in technology education. Final report. Brisbane: Griffith University.

Pavlova, M. (2003). Questioning the nature of technology education in the context of social change. In, E. Martin \& H.E. Middleton, (Eds.), Initiatives in technology education: Comparative perspectives (pp. 46-60). Brisbane: Technical Foundation of America \& Griffith.

Pavlova, M. (2008). Comparative analysis as a research method in technology education. In H.E. Middleton (Ed.), Researching technology education: Methods and techniques (pp. 116-154). In International Technology Education Series. Rotterdam/Taipei: Sense.

Pavlova, M. (in press). University - TAFE collaboration: Responses to the labour market. In D.Johnson and R. Maclean (Eds.), Vocational and Higher Education, Springer.

Smith, E. (2004). Vocational education and training in schools in Australia: What are the consequences of moving from the margins to mainstream? Journal of Vocational Education and Training, 56(4), 559-582.

Stevenson, J.C. (2008). Capturing knowledge and activity. In H.E. Middleton (Ed.), Researching technology education: Methods and techniques (pp. 155-171). In International Technology Education Series. Rotterdam/Taipei: Sense.

Walmsley, B. (2008). Using stimulated recall techniques in technology education classes. In H.E. Middleton (Ed.), Researching technology education: Methods and techniques (pp. 172-192). In International Technology Education Series. Rotterdam/Taipei: Sense. 


\section{HOWARD MIDDLETON}

Watts, D. (1997). A report on the readiness of Australian schools to meet the demands of teaching the curriculum areas of science and technology in the compulsory years of schooling. Perth: University of Notre Dame.

Williams, P.J. (2001). The teaching and learning of technology in Australian primary and secondary schools. Working report to the Department of Education, Science and Training (DEST). Canberra: AGPS.

Williams, P.J. (2002). Crisis in technology education in Australia. In H. E. Middleton, M. Pavlova, \& R. Roebuck. (Eds.), Learning in technology education: Challenges for the $21^{\text {st }}$ Century. Proceedings from the $2^{\text {nd }}$ Biennial Technology Education Research Conference, Volume 2 (pp. 272-281). Brisbane: Centre for Technology Education Research, Griffith University.

Williams, P.J. (2006). Technology teacher education in Australia. In P.J. Williams (Ed.), International technology teacher education: $55^{\text {th }}$ Yearbook (pp. 1-22). New York: Glencoe.

Howard Middleton

Griffith University, Australia 